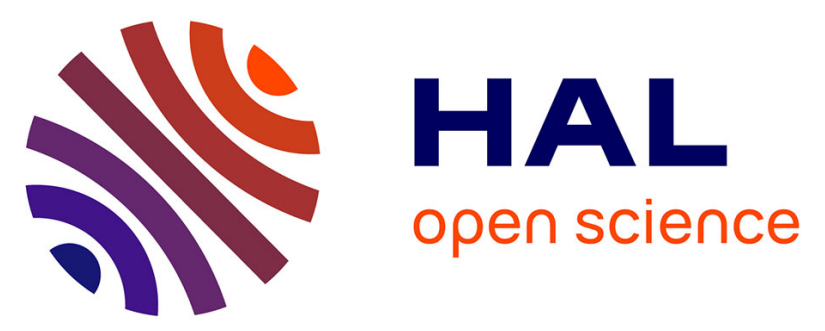

\title{
Role of insect vectors in epidemiology and invasion risk of Fusarium circinatum, and risk assessment of biological control of invasive Pinus contorta
}

Eckehard G. Brockerhoff, Margaret Dick, Rebecca Ganley, Alain Roques, Andrew J. Storer

\section{To cite this version:}

Eckehard G. Brockerhoff, Margaret Dick, Rebecca Ganley, Alain Roques, Andrew J. Storer. Role of insect vectors in epidemiology and invasion risk of Fusarium circinatum, and risk assessment of biological control of invasive Pinus contorta. Biological Invasions, 2016, 18 (4), pp.1177-1190. 10.1007/s10530016-1059-8 . hal-02632311

\section{HAL Id: hal-02632311 \\ https://hal.inrae.fr/hal-02632311}

Submitted on 27 May 2020

HAL is a multi-disciplinary open access archive for the deposit and dissemination of scientific research documents, whether they are published or not. The documents may come from teaching and research institutions in France or abroad, or from public or private research centers.
L'archive ouverte pluridisciplinaire HAL, est destinée au dépôt et à la diffusion de documents scientifiques de niveau recherche, publiés ou non, émanant des établissements d'enseignement et de recherche français ou étrangers, des laboratoires publics ou privés.

$$
\text { Copyright }
$$




\section{Role of insect vectors in epidemiology and invasion risk of Fusarium circinatum, and risk assessment of biological control of invasive Pinus contorta}

Eckehard G. Brockerhoff, Scion (New Zealand Forest Research Institute), Christchurch, New Zealand, e-mail: eckehard.brockerhoff@scionresearch.com

Margaret Dick, Scion (New Zealand Forest Research Institute), Rotorua, New Zealand, e-mail: margaret.dick@scionresearch.com

Rebecca Ganley, Scion (New Zealand Forest Research Institute), Rotorua, New Zealand, e-mail: rebecca.ganley@scionresearch.com

Alain Roques, INRA - UR0633, Zoologie Forestière, 2163 Av. Pomme de pin, CS 40001, 45075 Orléans, France, e-mail: alain.roques@orleans.inra.fr

Andrew J. Storer, School of Forest Resources and Environmental Science, Michigan Technological University, 1400 Townsend Drive, Houghton, MI 49931, USA, e-mail: storer@mtu.edu

\section{Correspondence:}

Eckehard G. Brockerhoff, Scion (New Zealand Forest Research Institute), Christchurch, New Zealand, e-mail: eckehard.brockerhoff@scionresearch.com, Tel +64 364 2949, Fax +64 364 2812 


\section{Abstract}

2 Pitch canker, caused by the pathogen Fusarium circinatum, is a serious disease of pines, Pinus

3 species. It is a threat to natural and planted pine forests, and to date it has invaded countries

4 across five continents. Pine-feeding insects can play a key role in the epidemiology of the

5 disease, as wounding agents allowing pathogen access or as vectors transmitting the pathogen

6 from infected to healthy trees. We reviewed the role of insects in the epidemiology of pitch

7 canker worldwide and assessed which insects are present in New Zealand that may act as

8 wounding agents or vectors to determine whether pathogen invasion could adversely affect Pinus

9 radiata plantation forests and urban trees. We also evaluated whether cone or seed insects of

10 pines could be introduced as biological control agents of invasive Pinus contorta and how this

11 may affect the impact of a potential F. circinatum invasion. As there are no native pines or other

12 Pinaceae in New Zealand, there are only few pine insects, mainly accidental introductions. None

13 of the insects recorded on pines in New Zealand is likely to be a vector, suggesting low disease

14 risk. Of six potentially suitable biocontrol candidates, the European pine cone weevil Pissodes

15 validirostris is the most promising regarding host specificity and impact on seed production, but

16 there is uncertainty about its ability to act as vector of F. circinatum. Our methodology to review

17 and evaluate the vector potential of pine associates can be used as a generic framework to assess

18 the potential impacts of F. circinatum invasion.

19

20 Keywords: Cone and seed insects; invasive alien species; pathogen vectors; pitch canker 
Pitch canker, caused by the pathogen Fusarium circinatum (Nirenberg and O’Donnell), is a serious disease of some pines (Pinus spp.) (Dick 1998; Gordon et al. 2001; Wingfield et al. 2008). Since the 1980’s it has emerged as a particularly damaging disease of Pinus radiata D.

Don in the native range of this pine in various parts of California (Storer et al. 1997; Gordon et al. 2001). The pathogen is assumed to originate from Mexico/Central America (Wingfield et al. 2008) from where it has invaded the United States, Haiti, Japan, South Africa, Chile, Spain, Brazil and Italy, affecting a range of pine species (Dwinell 1999; Wingfield et al. 2002; Carlucci et al. 2007; Wingfield et al. 2008; Pfenning et al. 2014). The extent of disease problems varies among regions and host species, and symptoms can be common in forests and plantations (as in Spain, for example), restricted to nurseries (as reported from Chile), or parks and gardens (as in Italy). In South Africa, where pitch canker was first detected in 1990 (Viljoen et al. 1994), the disease remained confined to nurseries until 2005 when an outbreak was reported in young plantations in the Western Cape Province (Coutinho et al. 2007). Several countries where the disease has not yet been recorded, including New Zealand, China, and Australia, are thought to have a climate that is suitable for establishment of the fungus and development of pitch canker disease (Ganley et al. 2009).

Studies in California have shown that bark-feeding insects as well as cone and seed insects play an important role in the infection process, as wounding agents of trees that may allow pathogen access or as vectors of the pathogen from infected to healthy trees (Fox et al. 1991; Hoover et al. 1996; Storer et al. 1998; Storer et al. 2004a). In New Zealand and other countries in the southern hemisphere where Pinus radiata is widely planted as an exotic tree, there are relatively few associated insects, mainly because no native Pinaceae are present, and consequently there are no 
native specialised insect herbivores. Occasionally, some native insects attack pines, although their direct impact is mostly benign. However, several insect pests of pines have become introduced over the years. Preliminary reviews of the role of insects associated with pines in New Zealand as potential vectors of $F$. circinatum have been provided by Gadgil et al. (2003) and Storer et al. (2004b). Currently, there appear to be few insects in New Zealand that are likely to act as vectors of the fungus, and this may limit the spread of the fungus and its impact on pine plantations, if it ever became established there. However, a formal analysis of the potential vectors of $F$. circinatum in New Zealand is not available.

Knowledge about any potential disease vectors and other insect associates is necessary to enable an informed response in the event of an incursion of $F$. circinatum and to evaluate the risk of spread (Gadgil et al. 2003; Ganley 2007; Fourrier et al. 2015). The vector issue is also important for an assessment of the risk of the potential intentional introduction of seed-feeding insects for biological control of wilding (invasive) Pinus contorta Loudon. Several pine species are now considered environmental weeds in New Zealand and other southern hemisphere countries (Richardson and Higgins 1998; Rundel et al. 2014). In some regions of New Zealand, pines have invaded natural or semi-natural grassland and scrub communities (Ledgard 1998). Although plantings of Pinus contorta were of limited extent, this species is now considered the most serious invader among the pines (Ledgard 1998). Options for biological control have been assessed (Brockerhoff and Kay 1998; Brockerhoff et al. 2004). Because several pine species are highly valued in plantation forestry and also in urban amenity plantings, the potential use of cone and seed insects is a favoured approach as such insects may reduce the spread of pines without affecting growth or causing damage to other parts of trees. In addition, most cone and seed insects are specialised, adapted species that exhibit a high degree of host plant specificity (Turgeon et al. 1994), therefore limiting risks to non-target plants. On the other hand, seed-eating 
74 insects may not be as effective as other types of biocontrol agents, and it remains to be determined whether their effect actually reduces plant spread rates (e.g., Rees and Paynter 1997).

Based on a review of cone and seed insects that attack Pinus contorta, considering host specificity, potential impact on seed production and other criteria, some insects are thought to show promise as potential biocontrol agents, both in New Zealand and South Africa (Brockerhoff and Kay 1998; Brockerhoff et al. 2004; Roques et al. 2004). However, it is feared that the introduction of such insects to New Zealand would greatly increase the risks associated with $F$. circinatum because the biocontrol agent may act as an additional, and potentially important, vector of the pitch canker pathogen. In South Africa, such concerns have halted plans to introduce a cone insect for biocontrol of invasive pines (Lennox et al. 2009), although there is renewed interest in the approach.

Here we review the role of insects in the epidemiology of pitch canker world-wide and assess which insects present in New Zealand may act as vectors. We also review the preliminary selection of biocontrol agents against invasive pines and explore the risks of introducing such biocontrol agents to New Zealand, particularly with regard to our current knowledge about implications for vectoring F. circinatum. Our specific objectives are:

i. $\quad$ to provide an overview of the insects associated with pitch canker and their role in disease epidemiology in the countries where the disease occurs to date;

ii. to review the native and introduced insects found on pines in New Zealand, to determine the likelihood of these species acting as vectors of $F$. circinatum;

iii. to evaluate the insects potentially suitable for biocontrol of Pinus contorta in New Zealand and to assess the risk of their introduction in relation to the potential establishment of F. circinatum; and 
iv. to develop a general framework for the assessment of risks associated with vectors of $F$. circinatum or similar pathogens that can also be used for other countries.

Wounding agents, vectors and carriers of Fusarium circinatum and their interactions with the pathogen

In some regions insects have been shown to play an important role in the infection process while in other regions insects appear to play a minor role. Associations with insects have been best studied in California where pitch canker has become a major disease of the native Pinus radiata, which is among the most susceptible species of pine (Correll et al. 1991; Adams et al. 1999; Storer et al. 2002). Insects can act as 'wounding agents' that allow the pathogen to enter the plant via the damaged cuticle or via tunnels such as those made by bark beetles. Some insects are 'carriers' because they carry inoculum from diseased plants they either visited or on which they have developed. However, in order to be classified as a 'vector', Leach's postulates need to be met (Leach 1940). These state that in addition to being associated with diseased plants, carrying the pathogen, and visiting susceptible plant hosts, an organism must be capable of successfully transmitting the pathogen to plants that were not yet infected under controlled conditions. Some wounding agents act concurrently as vectors but a vector can also cause an infection via a wound caused by another species. Not all carriers of inoculum are necessarily successful vectors, for example, if they are not causing any wounding that would be sufficient for transmission. It is therefore important to consider the differences in involvement of the various insects associated with diseased or healthy host plants and to classify each species accordingly (Table 1). 
122 Insects that feed subcortically on live trees or that wound live trees during exploratory host

123 feeding have been shown to vector the pitch canker pathogen in California, especially bark

124 beetles such as Ips paraconfusus (Fox et al. 1991) and twig beetles, Pityophthorus spp. (Storer et

125 al. 2004a; Erbilgin et al 2008; Table 1; see Supplementary Table S1 for an alphabetical listing of insect species). Twig beetles are thought to vector the pitch canker pathogen into pines also during exploratory feeding to find suitable host material. Baiting trees with pheromones of Pityophthorus setosus resulted in pitch canker infections on those trees despite the lack of colonization by the insect (Storer et al 2004a). Other habits that may result in wounding include shoot feeding and the creation of wounds during oviposition. The cone beetles, Conophthorus radiatae and Ernobius punctulatus are also confirmed vectors (Hoover et al. 1995, 1996; Table 1). Several other species, including shoot and foliage feeders, sap suckers and predatory insects are known wounding agents or carriers but none of these are known vectors (Table 1, Supplementary Table S1).

To assess the role of insects in the infection of trees by F. circinatum and the epidemiology of the disease, it is important to consider the life cycles of both the pathogen and potential vectors and the nature of potential interactions between these organisms. Fruit bodies of F. circinatum (known as sporodochia) containing thousands of asexual spores (conidia) may be produced on the surface of infected tissues when conditions are moist. These are dispersed by water-splash and can be carried in air currents throughout the year (Blakeslee et al. 1978; Correll et al. 1991). Spores can also be recovered from the surface bark of trees even when fruit bodies are not readily apparent (Adams et al. 1999). Two rounds of studies have been conducted where spore suspensions were sprayed on small trees in the field and the branches were then baited with twig beetle pheromones (Sakamoto et al. 2007). The results showed no difference in disease between treated and untreated trees. It is likely that spore loads were very high in these studies compared 
with what occurs naturally. It seems likely that the insects pick up spores in the tree, perhaps while chewing their way out though diseased tissue. Insects coming into contact with the sporodochia may readily pick up many of the sticky spores that are likely to adhere to the surface of the body and be trapped amongst hairs and other surface structures (e.g., Yamoah et al. 2011). Fox et al. (1990) reported the isolation of the pathogen from galleries of Ips spp. in Pinus radiata trees. The beetles carry propagules that presumably can include hyphal fragments as well as spores. By contrast, it is likely that the importance of casually acquiring spores from the tree surface is low. The risk of transmission appears to vary at different times of the year according to propagule loads on two Ips species (Erbilgin et al. 2008). Spore loads of twig beetles were considered an important factor in studies of the vector efficiency (Erbilgin et al. 2009).

Once infection has occurred the fungus colonises the sapwood and can be readily isolated from discoloured or resinous tissues (McCain et al. 1987; Correll et al. 1991). However, the fungus does not spread great distances within the wood. Infection of a cone, or a cone whorl, vectored by cone insects or other borers leads to death of the branch beyond the cone, with each dead branch being the result of a separate infection. Although unsightly, the branch and twig death that would result from infections transmitted by cone and seed insects would probably have relatively little impact on tree growth. Lesions on branches girdle the branch so the distal portion dies; spread down the branch or shoot is usually arrested at the node (Dwinell et al 1985; Gordon et al. 2001). Individual trees may thus sustain crown infections for many years. However, crown dieback can be extensive due to the multiple infections. Trunk infections are often initiated by bark beetles, and tree death will follow girdling of the stem from a number of separate infections and/or attacks by bark beetles. Multiple trunk attacks are required in order to kill the cambium around the circumference and for tree death to result (Gordon et al. 2001; Storer et al. 2002). Bark 
beetles (especially Ips spp. and Dendroctonus spp.) can cause considerable mortality of pines also in the absence of any other disease agents (e.g., Six and Wingfield 2011).

In the absence of insects vectoring $F$. circinatum to the trunk of the trees, any stem infections would be initiated through infection of wounds created by other causes including weather events (such as wind and hail), pruning or cone collection (Dwinell et al. 1985; Gordon et al. 2001). In New Zealand, wounds could also occur from bark stripping by native parrots (Dick 1998), although this is rare.

Spread of the pitch canker disease in nurseries is different from what occurs in forests. The fungus has been reported to be capable of spreading through nurseries very rapidly, with devastating losses recorded (Viljoen et al. 1994). Unlike in older trees, wounds are not required for infection of young seedlings. Insect-vectored transmission is apparently not important (Hurley et al. 2007). Unfortunately, in contrast to the majority of pine nursery diseases where diligent application of fungicides will generally reduce the impacts of pathogens, chemical control of pitch canker disease has been found to be relatively ineffective (M.J. Wingfield pers. com.). However, rigorous sanitation procedures can reduce disease incidence to insignificant levels in a nursery where all plants are containerised (Van Wyk et al. 2012). Based on this knowledge, we can predict with reasonable confidence the outcome of an introduction of $F$. circinatum to a nursery in New Zealand where plants are reared both as bare root in nursery beds and in containers (Gadgil et al. 2003). Eradication attempts are likely to result in nursery closure while soil fumigation is undertaken followed by a high level of sanitation. Although insects are not thought to be important in the disease epidemiology within nurseries, certain insects may be involved in spreading the disease from nurseries to surrounding forests. It is more likely that 
transmission of the fungus to a plantation would occur via out planting of asymptomatic infected seedlings from a nursery than by insects.

\section{Potential vectors present in New Zealand}

Where pines occur naturally there is a substantial fauna of associated insects. For example, in

North America (north of Mexico) over 1100 insect species have been recorded as feeding on pines, including about 30 introduced insect species (de Groot and Turgeon 1998). The majority of these species were classed as either monophagous (ca. 50\%) or oligophagous (ca. 30\%) (i.e., more or less specific to pines).

The New Zealand flora includes no native pines or any other native Pinaceae, and as a result there are no native insects that are closely associated with pines. However, several native insects, primarily polyphagous species, have colonised pines growing in New Zealand, usually occurring at low densities (e.g., Berndt et al. 2004). The most common insects found on pines in New Zealand are introduced species from the native range of pines, mainly from Europe and North America, such as a number of bark beetles and longhorned beetles (Brockerhoff et al. 2006).

To obtain an indication of the relative abundance of insects associated with pines in New Research Institute) (Bulman 1990). The database of forest health surveillance reports contains over 3000 records of formally identified insects. This provided a list of over 500 insect species although most of these represent incidental observations of species that do not feed on pines. Nevertheless, the results of this database query do reflect which pine-feeding insects are most 
commonly found on pines growing in New Zealand's plantation forests and as amenity trees.

These common associates are most likely to play a role in the epidemiology of the pitch canker disease, should it become established in New Zealand. By contrast, insects that are only rarely found on pines are probably irrelevant, especially if they have no feeding or other close relationship. The 25 most commonly recorded insect species on pines in New Zealand (Table 2) represent all the feeding guilds of insects that have been considered overseas with regard to their association with pitch canker, except for pine cone insects (of which there are none in New Zealand), and predators or parasitoids (of which several were recorded but at low frequencies).

These common associates were categorised with regard to the host status during attack (i.e., live or dead trees) using information from Scion's Forest Health Database and from the Forest and Timber Insects series (e.g., Brockerhoff and Hosking 2001). All species were then assessed for their potential to act as a wounding agent, carrier of F. circinatum inoculum, or vector (Table 2).

Currently there are no high-risk species in New Zealand that could act as vector of the pitch canker pathogen. Of the insect species that have been demonstrated to vector F. circinatum elsewhere, none are currently known to exist in New Zealand. Ernobius mollis, an alien anobiid, is the only species that occurs in New Zealand that has a congeneric species known to vector the pathogen in the United States. Ernobius mollis colonises and breeds mostly in dead trees and it is therefore unlikely to be able to vector the pathogen to live trees although it has occasionally been observed in Europe to colonize cones of Pinus brutia, Pseudotsuga menziesii and Sequaiodendron gigantea attacked by cone pyralids (Roques, 1983). Of the insects that have been recorded from Pinus radiata in New Zealand, it is those that feed subcortically on live trees or that wound live trees during exploratory host feeding (such as Ips paraconfusus and Pityophthorus setosus in California) that would represent the greatest concern regarding association with the pitch canker pathogen. No such species that is a confirmed vector is present 
in New Zealand (Table 2). Of the other species, Hylastes ater is a representative of a genus that

246 is known to carry the pathogen in the United States (Storer et al 2004b). In Spain, F. circinatum

247 has not been isolated from H. ater, however, another species in the same genus, Hylastes attenuatus, can be a carrier of the pathogen (Romón et al. 2007, 2008). Nevertheless, Hylastes ater is known to attack seedlings (for maturation feeding) and this could raise its risk status but based on current information, it is not thought to be a potential vector. Sirex noctilio is known to attack live pine trees but for several decades the species has been generally uncommon in New Zealand (Bain et al. 2011). Furthermore, it is not known to be a carrier of F. circinatum in any country where pitch canker occurs. Therefore, it is unlikely to become an important vector if $F$. circinatum became established in New Zealand.

Gadgil et al. (2003) list 14 sap-feeding species as potential vectors of the pitch canker pathogen in New Zealand, although most of these are not associated with pines. Among sap feeding species in California, only spittlebugs have been shown to be associated with pitch canker (Storer et al. 1998), even though other sap feeding species such as the Monterey pine scale, Physokermes insignicola (Homoptera: Coccidae), commonly occur in native and planted Pinus radiata forests in California. The absence of a spittlebug feeding on Pinus radiata in New Zealand and the apparent lack of association of the pathogen with other sap feeders suggests that these species should not be considered to be significant associates of F. circinatum in New Zealand.

\section{Potential biological control agents for invasive pines}

A preliminary evaluation of potential biological control agents against wilding pines in New 
contorta because it is considered the most important invader. Also, this pine has not been planted in commercial plantations for several decades, and biocontrol using seed-feeding insects is therefore less controversial than against a target species that is economically important (Brockerhoff and Kay 1998). A number of criteria were applied in the selection of potential agents including: the candidate agent should have a host range that includes the target species and subspecies, be sufficiently host specific such that it would not attack non-target tree species, be compatible with the climate in the target region(s) in New Zealand, reduce seed production of the target species substantially, and be able to disperse to isolated tree populations. In addition, the agent should not have any other unwanted effects such as a potential contribution to tree disease dynamics (see below). The survey focussed on cone insects within the natural range of Pinus contorta and also on cone insects that have colonised the species in areas where the tree was introduced, especially in parts of Europe. Based on this, 16 species were assessed (Brockerhoff and Kay 1998) of which six species were considered to be potentially suitable and worthy of further consideration and research (Table 3). The other species were insufficiently host specific or attacked other parts of trees, which could affect tree growth.

The North American cone moth Eucosma rescissoriana can significantly reduce seed production, but this species was disregarded on the basis of its wider host range that covers firs (Abies grandis, A. lasiocarpa) and pines (Pinus contorta, Pinus monticola and possibly Pinus albicaulis; Hedlin et al., 1980). However, the host range of this species should be reviewed as all other species of Eucosma are genus-specific, and it is unusual that Eucosma rescissoriana attacks both firs and pines. Three other species, the anobiid Ernobius nigrans, the cerambycid Paratimia conicola, and the tortricid Cydia toreuta, may be sufficiently host specific but they usually have a more limited effect on seed production, at least in their natural geographic range. Most promising were the pine cone beetle Conophthorus ponderosae, a North American species, and Pissodes 
validirostris, the European pine cone weevil. Both these species have a narrow host range and the ability to reduce seed production considerably (Brockerhoff and Kay 1998; Brockerhoff et al. 2004). However, Pissodes validirostris appeared to be the most effective in terms of its effects on seed production, possibly because the two species did not co-evolve, and Pinus contorta may not have developed adaptations against this particular cone insect. Based on these findings, we prioritised Pissodes validirostris as the agent of first choice for more detailed consideration and for potential introduction to New Zealand.

Out of a total of 21 insect species known to develop in the cones of Pinus spp. in Europe and in the Mediterranean basin, Pissodes validirostris is the most damaging cone insect (Roques 1983; Roques \& El Alaoui El Fels 2002). Most other species cause only minor damage. Pissodes validirostris is present all over the Palaearctic region from Portugal and Scandinavia to northern China (Roques 1983). Larvae of Pissodes validirostris develop exclusively in pine cones, tunneling through the tissues and destroying the seeds. They attack native pines of the subgenus Pinus such as Pinus sylvestris, $P$. mugo, $P$. uncinata, $P$. nigra and subspecies, and $P$. leucodermis which all belong to the subsection Pinus (Gernandt et al. 2005), as well as Mediterranean pines of the subsection Pinaster, such as $P$. pinaster, $P$. halepensis, and $P$. pinea) (Roques, 1983). Weevil attacks are also recorded on some North American pines widely planted in Europe such as lodgepole pine, Pinus contorta (Annila 1975; Delplanque et al. 1988), a species of the subgenus Pinus but from the section Trifoliae. Cone damage from $P$. validirostris was recently noticed in French arboreta on Pinus hartwegii (= P. rudis), a member of the subsection Ponderosae (Alain Roques, unpublished data). By contrast, the North American pines Pinus radiata and P. taeda, belonging to the subsection Australes of the subgenus Pinus, are not known to be attacked or damaged, despite the presence of large areas of planted forest of these species in parts of south-western Europe where Pissodes validirostris is generally very 

subgenus Strobus such as Swiss stone pine (Pinus cembra), are avoided (Dormont and Roques 1999) as are exotic pines of the same subgenus, probably due to specific host volatiles (Dormont and Roques 2001). However, host-specificity tests revealed that there are different biotypes of $P$. validirostris which specialize on pines either of the subsection Pinus or of the subsection Pinaster (Roques et al. 2004). Recent molecular and morphometric studies confirmed that the species Pissodes validirostris probably incorporates discrete taxa, or at least independent evolutionary lineages. At least three phylogeographic lineages were identified corresponding to the populations of the Iberian Peninsula, Central Europe and Northern/ Eastern Europe, respectively, which correspond to the differences in host plant preferences (Géraldine Roux, pers. comm.). Populations that colonized Pinus contorta are more closely associated with Central and Northern European populations on Pinus sylvestris than with those developing on Mediterranean

Cone damage by Pissodes validirostris greater than $80 \%$ has been reported from natural stands of

Pinus pinea in Spain (Bachiller 1966) and of Pinus sylvestris and Pinus uncinata in France (Roques 1977; Roques et al. 1983). However, Pinus contorta appears to be significantly more attacked than Pinus sylvestris when these two species are planted in proximity. In Finland, 42\% 94\% of Pinus contorta cones were damaged by Pissodes validirostris compared with 1\% - 55\% of Pinus sylvestris (Annila and Hiltunen 1977). In central France, cone damage in Pinus contorta was nearly twice the damage in $P$. sylvestris (82.0\% vs. 46.3\%) (Delplanque et al. 1988). Larvae 
of Pissodes validirostris affect seed yield by direct feeding and by inducing resin bleeding

346 (Roques 1976). Resin bleeding reduces seed dispersal by preventing the cone scales from opening (Roques 1976). In Pinus sylvestris, 3-4 larvae of P. validirostris are enough to destroy a cone completely (Roques 1976), but in pine species with larger cones (e.g., Pinus pinaster) the number of larvae must be greater than four to get the same result. In the small-sized cones of Pinus contorta, each weevil larva is responsible for a loss of 40 to $60 \%$ of the seed content (Delplanque et al. 1988) whilst the presence of 2 larvae per cone increases seed loss to ca. 80\% (Annila 1975).

\section{Risks associated with introducing biocontrol agents against invasive pines}

Based on the available information about potential effectiveness and non-target impacts, the most promising potential biocontrol agents against wilding pines in New Zealand are the ponderosa pine cone beetle, Conophthorus ponderosae, and the pine cone weevil, Pissodes validirostris (Brockerhoff and Kay 1998, above). In addition, the lodgepole pine cone moth, Eucosma rescissoriana, could be considered if it can be determined that it is sufficiently host specific. There are important issues that need to be addressed concerning the risk of these insects becoming vectors of the pitch canker pathogen and thereby causing unwanted damage of pines in planted forests. Biocontrol agents that enter the host tissues (as opposed to feeding externally) have a high potential to act as vectors of the pitch canker pathogen. In addition, those that cause wounds to branches and stems may also act as vectors as has been shown for twig beetles in the Western United States (e.g. Storer et al. 2004a). 
Conophthorus ponderosae has a congeneric species that is a confirmed vector of the pathogen in

California and therefore it may be a vector in New Zealand. Although Pinus radiata is not a known host species (Storer et al. 2004b), a host switch could occur.

The lodgepole pine cone moth, Eucosma rescissoriana, may become associated with the pitch canker pathogen as a vector or as a wounding agent. A shift in habit by this species to include the shoot feeding habit exhibited by other members of the genus could also increase the significance of any association with the pathogen.

Although larval and pupal development of Pissodes validirostris occurs entirely in seed cones, adult weevils require maturation feeding, typically on the pine leader shoots, in spring in order to become sexually mature and capable of laying eggs on cones (Roques 1976). Another period of feeding on leader shoots is observed in autumn before the adults settle to overwinter in the bark of the trees (Roques et al. 2004). In contrast to egg-laying, behavioral tests showed that the different biotypes of Pissodes validirostris can feed on the shoots of a large number of pine species. Such damage did not appear to affect plant health (Roques et al. 2004), but it may help fungal transmission. Fresh adults washed immediately after emergence from the cones did not carry any F. circinatum conidia (Lennox et al. 2009). In an experiment, feeding on Pinus radiata seedlings by adult $P$. validirostria that had been artificially infected with $F$. circinatum did not show any transmission of conidia. However, its feeding damage appeared to facilitate the ingress of the fungus into the host plant (Lennox et al. 2009).

Based on these findings, it cannot be ruled out that Pissodes validirostris, if it were introduced to New Zealand, could act as a vector of $F$. circinatum should the pathogen become established there. The behavior of this species would allow several types of association with the pitch canker 
pathogen including spreading the pathogen by dissemination through adults emerging with the pathogen, inoculation of the pathogen during egg laying and adult feeding, ingression through egg laying, adult and larval feeding, and invasion during larval feeding. The most likely responsible mechanism is the maturation feeding behaviour of this weevil. Furthermore, Pissodes validirostris has a demonstrated ability to colonise new hosts, such as Pinus contorta, and this represents a new insect-host plant association. The potential for additional changes in host use in new environments cannot be ruled out. If Pissodes validirostris were to colonise and damage cones of Pinus radiata, then it could also affect breeding programmes and the production of seed for nurseries.

\section{Conclusions}

The pitch canker disease caused by the pathogen $F$. circinatum represents a major threat to pine forests worldwide. Pinus radiata is one of the most susceptible pines, and it is an important tree in planted forests in New Zealand and several other countries where F. circinatum does not yet occur. In New Zealand, this risk is moderated by the fact that no known vectors of $F$. circinatum are present. Our review identified several species that could play a role in the epidemiology of the disease in New Zealand, as wounding agents or carriers of the pathogen, but no insects appear to be present that could act as effective vectors. Against this background, the proposed introduction of biocontrol agents against invasive Pinus contorta or other pines has been deemed too risky, mainly because of the pitch canker pathogen vectoring issue (Dick and Bain 2004). Furthermore, it is not certain how effective a biocontrol agent would be in terms of reducing the spread of wilding pines. While the success of past biocontrol introductions has been high, with 83\% providing partial or complete control of target plants, seed eating agents have perhaps been 
less effective (Fowler et al. 2000; Suckling 2013). A similar proposal to introduce seed eating insects for the control of invasive pines has been considered in South Africa (Hoffmann et al. 2011). Recently it has been decided not to pursue this further due to risks associated with pitch canker in South Africa where the disease is already present, and because of questions about the effectiveness of biocontrol relying solely on cone and seed insects (Lennox et al. 2009). Further research on insects present in New Zealand and on potential biocontrol agents could be conducted in regions where these species occur and where F. circinatum is also present (e.g., Spain and South Africa for some of the European insects). This would assist with further risk assessments and possible future incursion responses.

\section{Acknowledgements}

431 We thank John Bain for reviewing an earlier version of the manuscript. Funding for this review was obtained from the New Zealand Government (FRST contract C04X0302 and Better Border Biosecurity via MBIE core funding to Scion, contract C04X1104).

\section{References}

Adams DH, Frankel SJ, Tidwell TE (1999) Chronicle of pitch canker in California. In: Devey ME, Matheson AC, Gordon TR (eds.) Current and potential impacts of pitch canker in radiata pine, Proceedings of the IMPACT Monterey workshop, California, USA, 30

Annila E (1975) The biology of Pissodes validirostris Gyll. (Col. Curculionidae) and its harmfulness, especially in Scots pine seed orchards. Commun Inst For Fenn 85:1-95. 
Annila E, Hiltunen R (1977) Damage by Pissodes validirostris (Coleoptera, Curculionidae) studied in relation to the monoterpene composition in Scots pine and Lodgepole pine. Ann Entomol Fenn 43:87-92.

Bachiller P (1966) Estudio sobre la biologia y tratamientos del Pissodes validirostris Gyll. Boll Serv Plagas For 9:133-136.

Bain J, Sopow SL, Bulman LS (2011) The sirex woodwasp in New Zealand: history and current status. In: Slippers B, de Groot P, Wingfield MJ (eds) The sirex woodwasp and its fungal symbiont. Research and management of a worldwide invasive pest. Springer, Dordrecht, pp. 167-173.

Berndt LA, Brockerhoff EG, Jactel H, Weis T, Beaton J (2004) Biology and rearing of Pseudocoremia suavis, an endemic looper (Lepidoptera: Geometridae) with a history of outbreaks on exotic conifers. New Zeal Entomol 27:73-82.

Blakeslee GM, Oak SW, Gregory W, Moses CS (1978) Natural association of Fusarium moniliforme var. subglutinans with Pissodes nemorensis. Phytopathol News 12:208.

Blakeslee GM, Foltz JL (1981) The deodar weevil, a vector and wounding agent associated with pitch canker of slash pine. Phytopathology 71:861.

Brockerhoff EG, Kay M (1998) Prospects and risks of biological control of wilding Pinus contorta in New Zealand. Proceedings, 51st New Zealand Plant Protection Conference, New Zealand Plant Protection Society, pp. 216-223.

Brockerhoff EG, Hosking GP (2001) Arhopalus tristis (F.) (Coleoptera: Cerambycidae), burnt pine longhorn beetle. Forest and Timber Insects in New Zealand 27 (revised), Forest Research Institute (Scion), Rotorua, New Zealand, pp. 1-7.

Brockerhoff EG, Hoffmann J, Roques A (2004) Is biological control an option for the management of wilding pines (Pinus spp.) in New Zealand? In: Hill RL, Zydenbos SM, 
Bezar CM (eds.) Managing wilding conifers in New Zealand: Present and Future, New Zealand Plant Protection Society, Christchurch, pp. 65-78.

Brockerhoff EG, Jones DC, Kimberley MO, Suckling DM, Donaldson T (2006) Nation-wide survey for invasive wood boring and bark beetles (Coleoptera) using traps baited with pheromones and kairomones. Forest Ecol Manag 228:234-240.

Bulman LS (1990) BUGS and HEALTH — integral part of forest protection strategy. What's new in Forest Research No. 197. Forest Research Institute, Rotorua, New Zealand.

Carlucci A, Colatruglio L, Frisullo S (2007) First report of pitch canker caused by Fusarium

Correll JC, Gordon TR, McCain AH, Fox JW, Koehler CS, Wood DL, Schultz ME (1991) Pitch canker in California: pathogenicity, distribution and canker development on Monterey pine (Pinus radiata). Plant Dis 75:676-682.

Coutinho TA, Steenkamp ET, Mongwaketsi K, Wilmot M, Wingfield MJ (2007) First outbreak of pitch canker in a South African pine plantation. Australas Plant Path 36(3):256-261.

Dallara PL (1997) Studies on the distribution, interspecific relationships, host range, and chemical ecology of Pityophthorus spp. (Coleoptera: Scolytidae) and selected insectan associates, and their associations with Fusarium subglutinans f. sp. pini in central coastal California. Dissertation, University of California, Berkeley.

de Groot P, Turgeon JJ (1998) Insect-pine interactions. In: Richardson DA (ed.) Ecology and biogeography of Pinus. Cambridge University Press, Cambridge, pp. 354-380.

Delplanque A, Giovanini JP, Roques A, Augustin S (1988) Primeros problemas entomologicas consecutivos a la introduccion de Pinus contorta Douglas en Francia. Plagas Forestales $16: 123-132$.

Dick MA (1998) Pine pitch canker - the threat to New Zealand. New Zeal J For 42:30-34. 
Dick M, Bain J (2004) Biocontrol of wildings - could it be trouble? New Zeal Tree Grower 25(1):32.

Dormont L, Roques A (1999). A survey of insects attacking seed cones of Pinus cembra in the Alps, the Pyrenees and Massif Central. J Appl Entomol 123:65-72.

Dormont L, Roques A (2001) Why are seed cones of Swiss stone pine (Pinus cembra) not selection vs. host suitability. Entomol Exp Appl 99:157-163.

Dwinell LD, Barrows-Broaddus J, Kuhlman EG (1985) Pitch canker: a disease complex of southern pines. Plant Dis 69:270-276.

Dwinell LD (1999) Global distribution of the pitch canker fungus. In: Devey ME, Matheson AC, Gordon TR (eds.) Current and potential impacts of pitch canker in radiata pine, Proceedings of the IMPACT Monterey workshop, California, USA, 30 Nov. to 3 Dec. 1998, CSIRO Forestry and Forest Products Report No. 112, CSIRO, Canberra, pp. 54-57.

Erbilgin N, Storer AJ, Wood DL, Gordon TR (2005) Colonization of cut branches of five coniferous hosts of the pitch canker fungus by Pityophthorus spp. (Coleoptera: Scolytidae) in central, coastal California. Canadian Entomologist 137:337-349.

Erbilgin N, Ritokova G, Gordon TR, Wood DL, Storer AJ (2008) Temporal variation in contamination of pine engraver beetles with Fusarium circinatum in native Monterey pine forests in California. Plant Path 57:1103-1108.

Erbilgin N, Gordon TR, Wood DL, Storer AJ (2009) Bark beetle (Coleoptera: Scolytidae)mediated fungal infections of susceptible trees induce resistance to subsequent infections in a dose dependent manner. Agric For Entomol 11: 255-263.

Fourrier C, Antoine S, Piou D, Ioos R (2015) Rapid detection of Fusarium circinatum propagules on trapped pine beetles. Forest Pathol (in press). 
Fowler SV, Syrett P, Hill RL (2000) Success and safety in the biological control of environmental weeds in New Zealand. Austral Ecology 25:553-562.

518 Fox JW, Wood DL, Koehler CS (1990) Distribution and abundance of engraver beetles

Fox JW, Wood DL, Koehler CS, O’Keefe ST (1991) Engraver beetles (Scolytidae: Ips species)

Gadgil P, Dick M, Simpson J, Bejakovich D, Ross M, Bain J, Wylie R, Horgan G (2003) New Zealand. Unpublished report, Forest Research, Rotorua, New Zealand.

Ganley R (2007) Pitch canker - risk of establishment in New Zealand based on a global perspective. New Zeal J For 52(2):26-30.

Ganley RJ, Watt MS, Manning L, Iturritxa E (2009) A global climatic risk assessment of pitch canker disease. Can J Forest Res 39:2246-2256.

Gernandt DS, López GG, García SO, Liston A (2005) Phylogeny and classification of Pinus. Taxon 54:29-42.

Gordon TR, Storer AJ, Wood DL (2001) The pitch canker epidemic in California. Plant Dis 85:1128-1139.

Hedlin AF, Yates III HO, Cibrian-Tovar D, Ebel BH, Koerber TW, Merkel EP (1980) Cone and seed insects of North American conifers. Environment Canada, Canadian Forest Service, Ottawa; USDA Forest Service, Washington DC; Secr. Agric. Recur. Hidraul., Mexico, pp. 1-122.

Hoffmann JH, Moran VC, Van Wilgen BW (2011) Prospects for the biological control of invasive Pinus species (Pinaceae) in South Africa. Afr Entomol 19(2):393-401. 
Hoover K, Wood DL, Fox JW, Bros WE (1995) Quantitative and seasonal association of the pitch canker fungus, Fusarium subglutinans f. sp. pini, with Conophthorus radiatae (Coleoptera: Scolytidae) and Ernobius punctulatus (Coleoptera: Anobiidae) which infest Pinus radiata. Can Entomol 127:79-91.

545 Hoover K, Wood DL, Storer AJ, Fox JW, Bros WE. 1996. Transmission of the pitch canker

Hosking GP. 1978. Oemona hirta (Fabricius) (Coleoptera: Cerambycidae), lemon tree borer.

Hurley BP, Slippers B, Coutinho TA, Wingfield BD, Govender P, Wingfield MJ. 2007. Molecular detection of fungi carried by Bradysia difformis (Sciaridae: Diptera) in South African forestry nurseries. South Hemisph For J 69(2):103-109.

Iturritxa E, Ganley RJ, Wright J, Heppe E, Steenkamp ET, Gordon TR, Wingfield MJ (2011) A genetically homogenous population of Fusarium circinatum causes pitch canker of Pinus radiata in the Basque Country, Spain. Fungal Biol 115(3):288-295.

Keen FP (1958) Cone and seed insects of western forest trees. U.S. Dept. Agric., Tech. Bull. 1169:1-168.

559 Leach JB (1940) Insect transmission of plant diseases. McGraw-Hill, New York.

Ledgard NJ (1998) The spread of lodgepole pine (Pinus contorta, Dougl.) in New Zealand. Forest Ecol Manag 141:43-57.

Lennox CL, Hoffmann JH, Coutinho TA, Roques A (2009) A threat of exacerbating the spread of pitch canker precludes further consideration of a cone weevil, Pissodes validirostris, for biological control of invasive pines in South Africa. Biol Control 50:179-184. 
McCain AH, Koehler CS, Tjosvold SA (1987) Pitch canker threatens California pines. Calif Agric 41:22-23.

Matthews FR (1962) Pitch canker-tip moth damage association on slash pine seedlings. J Forest 60:825-826.

Pfenning LH, Costa SDS, Melo MPD, Costa H, Ventura JA, Auer CG, Santos ÁFD (2014). First

Romón P, Troya M, de Gamarra ME, Eguzkitza A, Iturrondobeitia J, Goldarazena A (2008) Fungal communities associated with pitch canker disease of Pinus radiata caused by Fusarium circinatum in northern Spain: association with insects and pathogen-saprophyte antagonistic interactions. Can J Plant Pathol 30:241-253. Roques A (1976) Observations sur la biologie et l'écologie de Pissodes validirostris Gyll. (Coléoptère, Curculionidae) en forêt de Fontainebleau. Ann Zool Ecol Anim 8:533-542. Roques A (1977) Etude du complexe entomologique lié aux cônes de pin sylvestre en forêt de Fontainebleau. B Ecol 8:415-434. 
Roques A (1983) Les insectes ravageurs des cônes et graines de conifères en France. INRA, Service des Publications, Versailles, France.

Roques A, El Alaoui El Fels MA (2002) Overview of the arthropod fauna exploiting seed cones in the Mediterranean Basin. In: Lieutier F, Ghaioule D (eds.), Entomological research in Mediterrannean forest ecosystems, INRA Editions, Versailles, France, pp. 59-78.

Roques A, Raimbault JP, Goussard F (1983) L'impact des insectes ravageurs des cônes et graines sur la régénération naturelle du Pin à crochets (Pinus uncinata Ram.) dans quelques forêts de montagne des Alpes du Sud et des Pyrénées Orientales. Acta Biol Montana 2:331-347.

Roques A, Roux-Morabito G, Hoffmann JH, Kleinhentz M, Gourov A (2004) Determining the suitability of a European cone weevil, Pissodes validirostris, for biological control of invasive pines in South Africa. In: Cullen JM, Briese DT, Kritikos DJ, Lonsdale WM, Morin L, Scott JK (eds.), Proceedings of the XI International Symposium on Biological Control of Weeds, 27 April - 2 May 2003, Canberra, Australia. CSIRO Entomology, Canberra, pp. 315-321.

Rundel PW, Dickie IA, Richardson DM (2014) Tree invasions into treeless areas: Mechanisms and ecosystem processes. Biol Invas 16:663-675.

Sakamoto JM, Gordon TR, Storer AJ, Wood DL (2007) The role of Pityophthorus spp. as vectors of pitch canker affecting Pinus radiata. Can Entomol 139:864-871.

Six DL, Wingfield MJ (2011) The role of phytopathogenicity in bark beetle-fungus symbioses: a challenge to the classic paradigm. Annu Rev Entomol 56:255-272.

Storer AJ, Gordon TR, Wood DL, Bonello P (1997) Pitch canker disease of pines: current and future impacts. J Forest 95:21-26.

Storer AJ, Wood DL, Wikler KR, Gordon TR (1998) Association between a native spittlebug (Homoptera: Cercopidae) on Monterey pine and an introduced tree pathogen which causes pitch canker disease. Can Entomol 130:783-792. 
Storer AJ, Wood DL, Gordon TR (2002) The epidemiology of pitch canker of Monterey pine in California. Forest Sci 48:694-700.

Storer AJ, Wood DL, Gordon TR (2004a) Twig beetles, Pityophthorus spp. (Coleoptera: Scolytidae), as vectors of the pitch canker pathogen in California. Can Entomol 136:685693.

Storer AJ, Wood DL, Gordon TR (2004b) Could biological control of wilding pines increase the (eds.) Managing wilding conifers in New Zealand: Present and Future. New Zealand Plant Protection Society, Christchurch, pp. 97-111.

Suckling DM (2013) Benefits from biological control of weeds in New Zealand range from negligible to massive: A retrospective analysis. Biol Control 66:27-32.

Turgeon JJ, Roques A, de Groot P (1994) Insect fauna of coniferous seed cones: diversity, host plant interactions, and management. Annu Rev Entomol 39:179-212.

Van Wyk SJP, Boutigny A-L, Coutinho TA, Viljoen A (2012) Sanitation of a South African forestry nursery contaminated with Fusarium circinatum using hydrogen peroxide at specific oxidation reduction potentials. Plant Dis 96:875-880.

Viljoen A, Wingfield MJ, Marasas WFO (1994) First report of Fusarium subglutinans f. sp. pini on seedlings in South Africa. Plant Dis 78:309-312.

Viljoen A, Wingfield MJ, Marasas WFO, Coutinho TA (1997) Pitch canker of pines: a contemporary review. S Afr J Sci 93(9):411-413.

Wingfield MJ, Jacobs A, Coutinho TA, Ahumada R, Wingfield BD (2002) First report of the pitch canker fungus, Fusarium circinatum, on pines in Chile. Plant Pathol 51:397.

Wingfield MJ, Hammerbacher A, Ganley RJ, Steenkamp ET, Gordon TR, Wingfield BD, Coutinho TA (2008) Pitch canker caused by Fusarium circinatum - a growing threat to pine plantations and forests worldwide. Australas Plant Path 37, 319-334. 
640 Yamoah E, Jones EE, Suckling DM, Bourdôt GW, Walter M, Stewart A. 2011. Using insects as 641 potential vectors of Fusarium tumidum to control gorse. New Zeal Entomol 34:5-11. 
Table 1. Insects associated with Fusarium circinatum in regions where pitch canker occurs and the nature of their association. See Supplementary Table S1 for an alphabetical listing of insect species.

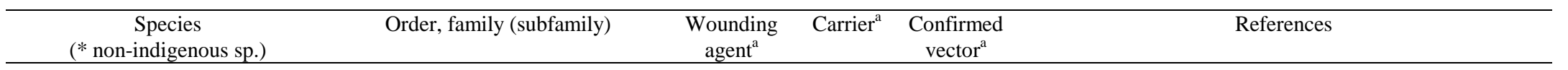

\section{USA (SOUTH-EAST)}

Bark beetles and wood borers

Pissodes nemorensis

Shoot and foliage-feeders

Rhyacionia spp.

Contarinia spp.

Cone insects

Cydia spp.

Leptoglossus corculus

\section{USA (CALIFORNIA)}

\section{Bark beetles and wood borers}

Ips paraconfusus

Ips mexicanus,

Ips plastographus maritimus

Pityophthorus setosus

Pityophthorus carmeli

Hylastes spp.

Hylurgops spp.

Dendroctonus valens

Pissodes radiatae

Sapsuckers

Aphrophora canadensis

Shoot and foliage-feeders

(none)

Cone insects

Conophthorus radiatae

Ernobius punctulatus

Predatory insects

Enoclerus sphegeus

Lasconotus spp.

Medetera spp.

Non-insect taxa

Snails and Pillbugs/Sowbugs
Col., Curculionidae, Molytinae

Lepidoptera, Tortricidae

Diptera, Cecidomyiidae

Lepidoptera, Tortricidae

Heteroptera, Coreidae

Col., Curculionidae, Scolytinae

Col., Curculionidae, Scolytinae

Col., Curculionidae, Scolytinae

Col., Curculionidae, Scolytinae

Col., Curculionidae, Scolytinae

Col., Curculionidae, Scolytinae

Col., Curculionidae, Scolytinae

Col., Curculionidae, Scolytinae

Col., Curculionidae, Molytinae?

Homoptera, Cercopidae

Col., Curculionidae, Scolytinae

Col., Anobiidae

Col., Cleridae

Col., Colydiidae

Dipt: Dolychopodidae

Mollusca and Crustacea (Isopoda)

Blakeslee et al. 1978, Blakeslee and Foltz 1981

Matthews 1962

Dwinell et al. 1985

Dwinell et al. 1985

Dwinell et al. 1985

$\begin{array}{ll}+ & \text { Dwinell et al. } 1985 \\ + & \text { Dwinell et al. } 1985\end{array}$

$(+)$

$(+)$

$+$

$(+)$

$(+)$

$(+)$

$+$

$+$

$+$

$+$
Fox et al. 1991

(+) Fox et al. 1991, Erbilgin et al. 2008

(+) Fox et al. 1991, Erbilgin et al. 2008

$+\quad$ Hoover et al. 1995, Storer et al. 2004a, Erbilgin et al. 2005

(+) Hoover et al. 1995, Storer et al. 2004a, Erbilgin et al. 2005 Storer et al. 2004b

Storer et al. 2004b

Storer et al. 2004b

Storer et al. 2004b

Storer et al. 1998

Mis en forme : Français (France) Mis en forme : Français (France)

Mis en forme : Français (France)

Mis en forme : Français (France) 
SOUTH AFRICA

Shoot and foliage-feeders

Pissodes nemorensis*

Col., Curculionidae, Molytinae

Diptera, Sciaridae

(?) Coutinho et al. 2007

Bradysia difformis

Hurley et al. 2007

CHILE

Bark beetles and wood borers

Hylastes ater*

Wingfield et al. 2008

JAPAN

None (?, see text)

\section{SPAIN}

Bark beetles and wood borers

Hylastes attenuatus

Hylurgops palliatus

Hypothenemus eruditus

Ips sexdentatus

Orthotomicus erosus

Pissodes castaneus

Pityophthorus pubescens

Tomicus piniperda

Cone insects

Pissodes validirostris

Root borers

Brachyderes incanus

Col., Curculionidae, Scolytinae

Col., Curculionidae, Scolytinae

Col., Curculionidae, Scolytinae

Col., Curculionidae, Scolytinae

Col., Curculionidae, Molytinae

Col., Curculionidae, Scolytinae

Col., Curculionidae, Scolytinae

Col., Curculionidae, Molytinae

Col., Curculionidae, Entiminae

Viljoen et al. 1997

Romón et al. 2007

Romón et al. 2007

Romón et al. 2007

Romón et al. 2007

Romón et al. 2007

Iturritxa et al. 2011

Romón et al. 2007, Iturritxa et al. 2011

Iturritxa et al. 2011

Roques et al. 2004, Lennox et al. 2009

$+\quad(?)$

$\left(^{+}++_{-} \quad\right.$ Romón et al. 2007

${ }^{\mathrm{a}}$ Nature of association: +, confirmed association; (+), presumed association not yet verified; (?), suspected but less likely or unknown association (for details see text) 
Table 2. Insects present in New Zealand that may act as associates with Fusarium circinatum.

\begin{tabular}{|c|c|c|c|c|c|}
\hline $\begin{array}{c}\text { Species } \\
(* \text { non-indigenous sp.) }\end{array}$ & Family (subfamily) & $\begin{array}{c}\text { Origin } \\
\text { (native region) }\end{array}$ & \multicolumn{2}{|c|}{$\begin{array}{l}\text { Attacks live (L) } \\
\text { or dead plants } \\
(\mathrm{D})^{\mathrm{a}}\end{array}$} & $\begin{array}{c}\text { Potential pitch } \\
\text { canker } \\
\text { association }^{\mathrm{b}} \\
\end{array}$ \\
\hline \multicolumn{6}{|l|}{ Bark beetles and wood borers } \\
\hline Hylastes ater* & Curculionidae, Scolytinae & Europe & $(\mathrm{L})^{\mathrm{a}}$ & $\mathrm{D}$ & $\mathrm{W}, \mathrm{C}$ \\
\hline Hylurgus ligniperda* & Curculionidae, Scolytinae & Europe & & $\mathrm{D}$ & $\mathrm{C}$ \\
\hline Pachycotes peregrinus & Curculionidae, Scolytinae & NZ & & $\mathrm{D}$ & $\mathrm{C}$ \\
\hline Platypus apicalis & Curculionidae, Platypodinae & NZ & & $\mathrm{D}$ & C \\
\hline Arhopalus ferus* & Cerambycidae & Europe & $(\mathrm{L})^{\mathrm{a}}$ & $\mathrm{D}$ & (W), C \\
\hline Calliprason pallidus & Cerambycidae & NZ & & $\mathrm{D}$ & $\mathrm{C}$ \\
\hline Hexatricha pulverulenta & Cerambycidae & NZ & $(\mathrm{L})^{\mathrm{a}}$ & $\mathrm{D}$ & $\mathrm{C}$ \\
\hline Oemona hirta & Cerambycidae & NZ & $(\mathrm{L})^{\mathrm{a}}$ & $\mathrm{D}$ & $(\mathrm{W}),(\mathrm{C})$ \\
\hline Prionoplus reticularis & Cerambycidae & NZ & & $\mathrm{D}$ & $\mathrm{C}$ \\
\hline Ernobius mollis* & Anobiidae & Cosmopolitan & & $\mathrm{D}$ & $\mathrm{C}$ \\
\hline Sirex noctilio* & Siricidae & Europe & $\mathrm{L}$ & & $\mathrm{C}$ \\
\hline Mitrastethus baridioides & Curculionidae, Cryptorhynchinae & NZ & & $\mathrm{D}$ & (C) \\
\hline Pycnomerus sophorae & Colydiidae & NZ & & $\mathrm{D}$ & (C) \\
\hline \multicolumn{6}{|l|}{ Shoot and foliage-feeders } \\
\hline Pseudocoremia suavis & Geometridae & NZ & $\mathrm{L}$ & & $\mathrm{W},(\mathrm{C})$ \\
\hline Hierodoris atychioides & Oecophoridae & NZ & $\mathrm{L}$ & & $\mathrm{W},(\mathrm{C})$ \\
\hline Ctenopseustis obliquana & Tortricidae & NZ & $\mathrm{L}$ & & $\mathrm{W},(\mathrm{C})$ \\
\hline Epiphyas postvittana* & Tortricidae & Australia & $\mathrm{L}$ & & $\mathrm{W},(\mathrm{C})$ \\
\hline Planotortrix notophaea & Tortricidae & NZ & $\mathrm{L}$ & & $\mathrm{W},(\mathrm{C})$ \\
\hline \multicolumn{6}{|l|}{ Sapsuckers } \\
\hline Pineus boerneri* & Adelgidae & USA & $\mathrm{L}$ & & $(\mathrm{W}),(\mathrm{C})$ \\
\hline P. pini* & Adelgidae & Europe & $\mathrm{L}$ & & (W), (C) \\
\hline Essigella californica* & Aphididae & USA & $\mathrm{L}$ & & (W), (C) \\
\hline Eulachnus brevipilosus* & Aphididae & Europe & $\mathrm{L}$ & & (W), (C) \\
\hline Heliothrips haemorrhoidalis* & Thripidae & Cosmopolitan? & $\mathrm{L}$ & & (W), (C) \\
\hline \multicolumn{6}{|l|}{ Cone insects } \\
\hline Erechthias fulguritella & Tineidae & $\mathrm{NZ}$ & (?) & & (?) \\
\hline
\end{tabular}

\footnotetext{
${ }^{a}$ Hylates ater sometimes attacks pine seedlings for maturation feeding; Arhopalus ferus has been recorded as attacking live trees but this is rare and probably limited to fire-damaged trees; Hexatricha pulverulenta sometimes breeds in pines, always dead trees, but occasionally it feeds on green twigs of pine (Bain and Hosking 1988);

Oemona hirta is normally associated with hardwood trees and attacks of softwoods are very rare (Hosking 1978).

${ }^{\mathrm{b}}$ Possible association in case of establishment of F. circinatum in New Zealand: W, wounding agent of live trees; C, carrier; $\mathrm{V}$, vector; values in brackets indicate uncertainty of association; (see text for details).
} 
Table 3. Most promising candidate agents for biocontrol of Pinus contorta in New Zealand, their characteristics, and potential for involvement with the pitch canker disease.

\begin{tabular}{|c|c|c|c|c|}
\hline Species & Family (subfamily) & Host range $^{b}$ & $\begin{array}{c}\text { Host structures } \\
\text { attacked }\end{array}$ & $\begin{array}{c}\text { Potential pitch } \\
\text { canker association }^{\text {e }}\end{array}$ \\
\hline \multicolumn{5}{|l|}{ Coleoptera } \\
\hline Conophthorus ponderosae & Curculionidae & Pinus spp., not $P$. radiata & $\begin{array}{l}\text { Only seed } \\
\text { cones }\end{array}$ & W, C, (V) \\
\hline Ernobius nigrans & Anobiidae & Pinus spp., not $P$. radiata & $\begin{array}{l}\text { Only seed } \\
\text { cones }\end{array}$ & W, C, (V) \\
\hline Paratimia conicola & Cerambycidae & Pinus spp., not $P$. radiata & $\begin{array}{l}\text { Only seed } \\
\text { cones }\end{array}$ & W, C, (V) \\
\hline Pissodes validirostris & Curculionidae & Pinus spp., not $P$. radiata $^{c}$ & $\begin{array}{l}\text { Mainly seed } \\
\text { cones }^{\mathrm{d}}\end{array}$ & $\mathrm{W}, \mathrm{C},(\mathrm{V})$ \\
\hline \multicolumn{5}{|l|}{ Lepidoptera } \\
\hline Cydia toreuta & Tortricidae & Pinus spp., not $P$. radiata & $\begin{array}{l}\text { Only seed } \\
\text { cones }\end{array}$ & W, C, (V?) \\
\hline Eucosma rescissoriana & Tortricidae & $\begin{array}{l}\text { Pinus and Abies spp., not } \\
\text { P. radiata }\end{array}$ & $\begin{array}{l}\text { Only seed } \\
\text { cones }\end{array}$ & W, C, (V?) \\
\hline
\end{tabular}

\footnotetext{
${ }^{a}$ Preliminary selection of potential agents according to Brockerhoff and Kay (1998) and Brockerhoff et al. (2004)

${ }^{\mathrm{b}}$ Host range information based on Keen (1958), Hedlin et al. (1980) and other publications listed in Brockerhoff and Kay (1998).

${ }^{\mathrm{c}}$ Depending on the subspecies / host race of $P$. validirostris (see text).

${ }^{\mathrm{d}}$ Maturation feeding, apparently causing little damage, may occur on shoots (see text).

${ }^{\mathrm{e}}$ Possible association in case of establishment of Fusarium circinatum in New Zealand: W, wounding agent of live trees; C, carrier; V, vector; values in brackets indicate uncertainty of association; (for details see text)
} 